\title{
PKM Karya Tulis Ilmiah
}

\author{
Hajrah Hamzah ${ }^{1}$, Sahade ${ }^{2}$ \\ ${ }^{1}$ Prodi Akuntansi S1, Fakultas Ekonomi, Universitas Negeri Makassar \\ 2 Prodi Pendidikan Akuntansi S1, Fakultas Ekonomi, Universitas Negeri Makassar
}

\begin{abstract}
The Community Partnership Program (PKM) partners are teachers of SD Pangkep. The problems are: (1) lack of knowledge about scientific writing (2) lack of skills in writing scientific papers and, (3) teachers at SD Pangkep in carrying out their functions are required to be professionally. The external target is the process of compiling Scientific Writing. The methods used are: lectures, demonstrations, discussions, questions and answers, and companion partners. The results achieved are (1) partners have knowledge in the field of Scientific Writing, (2) partners have the skills to compile Scientific Writing and, (3) partners have the ability to increase knowledge of the ability to write Scientific Papers.
\end{abstract}

Keywords: Scientific Papers, Teachers

\section{PENDAHULUAN}

UU No. 14 Tahun 2015 pasal 10 ayat 1 berisi tentang seorang guru memiliki syarat kompetensi pedagogik, kepribadian, sosial dan professional yang didapat melalui jalur pendidikan profesi. Guru yang professional tidak hanya dituntut untuk menguasai materi pembelajran tetapi juga mampu mengikuti perkembangan teknologi informasi dan komunikasi. Guru sebagai agen pendidikan diiharapkan bekerja secara professional dalam melaksanakan tugas dan tanggung jawabnya. Dalam dunia pendidikan guru berperan penting untuk mendidik anak didik agar memiliki kualitas pendidikan yang baik.

Pada hakikatnya, guru dengan tugas utamanya mengajar, diharapkan memiliki inovasi, kreasi, mengkaji, dan mengamati berbagai hal dalam dunia pendidikan. Guru sebagai seorang pengamat, dituntut memiliki rasa ingin tahu yang tinggi. Negara-negara maju mengedepankan pendidkan sebagai faktor penentu masa depan bangsa, diantaranya Jepang dan Malaysia.

Guru dengan tanggung jawabnya mengarahkan anak didik menjadi manusia yang berilmu pengetahuan di masa depan. Apabila guru bersikap pasif dan tidak berinovasi, maka pendidikan di negara kita akan ketinggalan dibanding negara lainnya.
Guru dituntut semaksimal mungkin untuk melakukan berbagai kegiatan pengembangan diri secara professional. Salah satu kegiatan profesional yang harus dimiliki oleh guru adalah menyampaikan informasi di forum-forum ilmiah terkait dengan dengan berbagai pemikiran dan penelitian yang dilakukan. Pada kenyataannya guru-guru belum memiliki kemampuan yang memadai dalam keterampilan berbahasa khususnya keterampilan menulis. Di samping itu, guru SD belum dapat mengembangkan diri secara optimal karena keterbatasan SDM yang memahami bagaimana cara menuangkan ide ke dalam Karya Tulis Ilmiah (KTI) dan aspek apa saja yang harus ada dalam KTI.

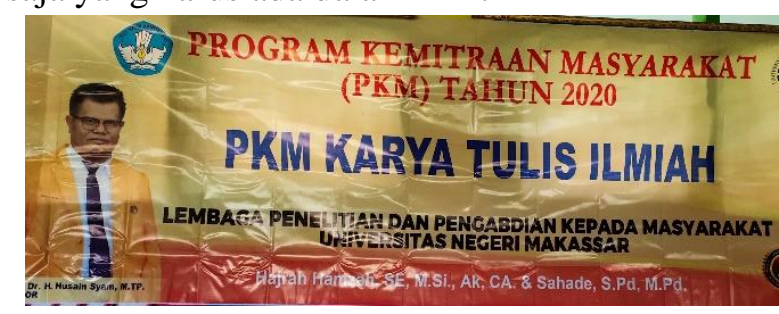

Gambar 1. Spanduk kegiatan PKM

Berdasarkan kondisi tersebut, dipertimbangkan perlu dilaksanakan kegiatan pelatihan penulisan karya ilmiah untuk guru-guru SD di Kecamatan Labakkang Kabupaten Pangkep, di fokuskan pada peningkatan kemampuan dan kemauan (motivasi) guru-guru dalam menulis karya ilmiah. Dengan pelatihan ini, guru-guru diharapkan bisa menjadi lebih produktif dalam menghasilkan Karya Tulis 
Ilmiah. Dengan demikian, aktivitas produksi menulis KTI dapat dilakukan dalam bentuk pelatihan.

Penulisan KTI merupakan sesuatu yang menarik untuk dilakukan pada segenap guru SD Kecamatan Labakkang Kabupaten Pangkep. Hal ini mengingat bahwa KTI merupakan salah satu tugas yang harus dipenuhi guru untuk mengukur kinerja yang dilakukan. Sementara guru SD Pangkep belum secara keseluruhan memiliki motivasi untuk memproduksi KTI karena belum memiliki pengetahuan dan keterampilan menulis yang memadai. KTI merupakan salah satu indikator untuk mengukur kinerja guru yang tercantum dalam akreditasi sekolah.

Guru SD Kecamatan Labakkang Kabupaten Pangkep pada dasarnya telah memiliki kompetensi keterampilan dalam aspek bahasa, yaitu berbicara, karena guru setiap hari harus berkomunikasi dengan peserta didik. Sementara itu, kondisi yang ada bahwa keterampilan berbicara yang dimiliki guru belum seimbang dengan keterampilan menulis. Guru kesulitan untuk menentukan topik, mengawali suatu tulisan, dan mengembangkannya dalam bentuk tulisan yang baik. Untuk itu perlu dilakukan PKM KTI SD Pangkep dalam bentuk laporan penelitian maupun penulisan artikel dalam jurnal ilmiah. Dengan demikian, soft skill keterampilan menulis guru dapat meningkat seiring dengan pemenuhan prasyarat pengusulan kenaikan pangkat.

Rendahnya produktivitas KTI disebabkan oleh hal-hal sebagai berikut.

1) Pengetahuan guru dalam KTI masih kurang. Hasil survei menunjukkan bahwa $70 \%$ guru SD Kecamatan Labakkang Kabupaten Pangkep belum mempunyai pengetahuan menulis karya ilmiah.

2) Kemampuan guru SD Kecamatan Labakkang Kabupaten Pangkep dalam memproduksi KTI masih terbatas. Hal ini sesuai jumlah guru yang belum mampu memproduksi KTI $70 \%$.

3) Untuk peningkatan kompetensi guru dalam menulis diperlukan pelatihan KTI bagi guru
SD Kecamatan Labakkang Kabupaten Pangkep.

Kompetensi guru dalam KTI perlu ditingkatkan mengingat tuntutan yang harus dipenuhi guru dalam menjalankan profesional.

\section{METODE YANG DIGUNAKAN}

Perguruan tinggi berperan aktif dalam mengembangkan bidang keahlian dari para pakar dan ahli di bidang pendidikan masing-masing dalam memajukan pengetahuan dan keahlian masyarakat. Seperti yang dilakukan Universitas Negeri Makassar. Hajrah Hamzah, SE, M.Si, Ak, CA Sebagai dosen Program Studi Akuntansi S1, Fakultas Ekonomi Universitas Negeri Makassar diharapkan menyelenggarakan kegiatan penulisan Karya Tulis Ilmiah di SD Kecamatan Labakkang Kabupaten Pangkep. Diharapkan para peserta dapat mengambil manfaat selama proses pelatihan. Kedepannya mereka dapat mengaplikasikan hasil pelatihan ini dan mampu mensosialisaikan kepada masyarakat lainnya.

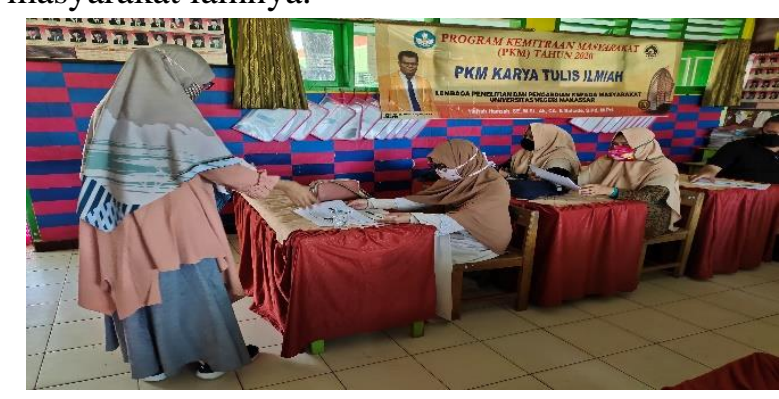

Gambar 2. Kegiatan Pelatihan

a. Dalam kegiatan pengabdian kepada masyarakat ini digunakan metode ceramah, tanya jawab, latihan, dan diskusi. Kegiatan pelatihan ini difokuskan pada penyusunan laporan keuangan kepada guru-guru SD Kecamatan Labakkang Kabupaten Pangkep Proses pelaksanaan kegiatan pengabdian kepada masyarakat ini dilakukan melalui pelatihan komputer akuntansi bagi guru-guru SD Pangkep dimulai dari tahap persiapan, pelaksanaan dan evaluasi. 


\section{PELAKSANAAN DAN HASIL KEGIATAN}

Khalayak sasaran umum kegiatan pengabdian bagi masyarakat ini adalah guru-gurui SD Kecamatan Labakkang Kabupaten Pangkep.. Namun yang menjadi sasaran khusus adalah guruguru SD Kecamatan Labakkang dengan peserta pelatihan sebanyak 15 orang.

Dari 15 orang yang ada di SD Pangkep Pangkep diharapkan dari hasil kegiatan pelatihan minimal 10 orang peserta pelatihan yang sudah memiliki pengetahuan dan keterampilan yang sangat baik, sehingga 10 orang ini dapat menyebar luaskan pengetahuan dan keterampilan mereka dalam menyusun laporan keuangan bagi guru-guru SD di Kabupaten Pangkep yang lainnya sehingga ke depan di SD Kabupaten Pangkep mampu mengaplikasikan pegetahuan mereka mengenai penyusunan Karya Tulis Ilmiah.

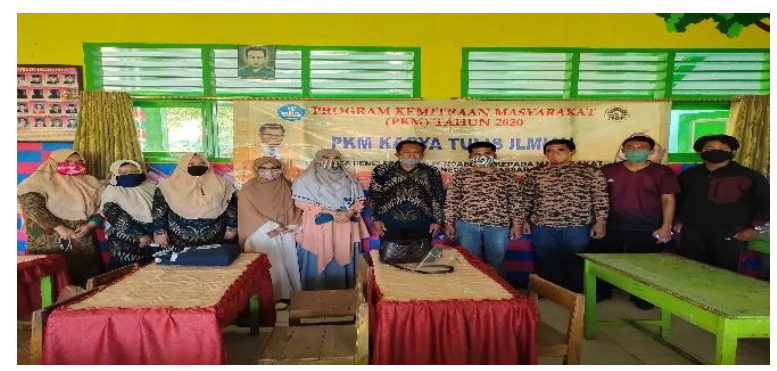

Gambar 3. Kegiatan PKM

\section{Materi Kegiatan}

Materi pelatihan pada kegiatan pengabdian kepada masyarakat yang dilaksanakan di SD Kecamatan Labakkang Kabupaten Pangkep terdiri atas:

\section{A. Konsep Dasar Karya Ilmiah}

Karya tulis ilmiah merupakan tulisan yang membahas ilmu pengetahuan yang disusun secara sistematis dengan menggunakan bahasa yang benar. Syarat minimal dalam sebuah karya ilmiah:

1. Menggunakan bahasa tulis sebagai media

2. Membahas konsep ilmu pengetahuan

3. Disusun secara sistematis

4. Dituangkan dengan menggunakan bahasa yang benar

- Ciri-ciri karya ilmiah:
1. Objektif, artinya memiliki objek dan memberikan penilaian secara objektif terhadap objek tersebut,

2. Faktual, artinya dibuat berdasarkan fakta yang dapat dipertanggungjawabkan kebenarannya,

3. Bermetode artinya disusun berdasarkan metode ilmiah tertentu,

4. Cermat dan jujur artinya mengangkat hal yang sebenarnya.

- Tujuan penulisan karya ilmiah:

1. Memecahkan masalah tertentu.

2. Menambah pengetahuan, ilmu, dan konsep pengetahuan tentang satu pokok masalah tertentu.

3. Membina kemampuan menulis ilmiah dan berpikir ilmiah bagi penulisnya.

- Karya ilmiah memiliki beberapa fungsi:

1. Fungsi pendidikan

2. Fungsi penelitian (sebagai sarana untuk menerapkan prosedur ilmiah dalam usaha mengembangkan ilmu pengetahuan)

3. Fungsi pengembangan (alat pengembangan ilmu, tambahan bahan pustaka)

- Jenis Karya Tulis Ilmiah:

1. Makalah: merupakan karya ilmiah yang berisi ide berdasarkan pada studi pustaka atau kajian lapangan, sebagai syarat penyelesaian tugas pada salah satu mata kuliah. Karena itu, cukup dengan membaca beberapa buku yang berkenaan dengan mata kuliah tersebut, kemudian menyusun laporan tertulisnya.

2. Laporan Penelitian: merupakan karya ilmiah yang biasanya disusun dengan tujuan untuk menyajikan/melaporkan kegiatan penelitian yang telah dilaksanakan.

3. Skripsi merupakan karya tulis ilmiah resmi yang membahas permasalahan dalam bidang tertentu. (syarat $\mathrm{S}-1$ )

4. Tesis adalah karya tulis ilmiah resmi berfokus pada pengujian teori yang telah ada dalam satu disiplin ilmu tertentu. (syarat S-2).

5. Disertasi merupakan karya ilmiah yang memiliki karakteristik: (a) berfokus pada penemuan sesuatu yang baru dalam disiplin ilmu tertentu, (b) berfokus pada pengembangan 
prinsip-prinsip teori yang telah ada, dan (c) berisi pengembangan model-model baru yang diuji di lapangan. (syarat S-3).

6. Karya ilmiah populer biasanya ditulis dengan teknik penulisan yang menarik agar mudah dimengerti pembacanya namun tetap mempertahankan kebenaran ilmiah/objektif

7. Kertas kerja merupakan salah satu jenis karya ilmiah yang disusun dengan tujuan untuk melaporkan satu kegiatan tertentu yang telah dilaksanakan oleh penulisnya (laporan kegiatan atau laporan kerja, misalnya KKN, PKL, kerja laboratorium) Sistematika dan teknik penulis kertas kerja biasanya akan sangat bergantung pada lembaga terkait.

B. Tahapan Penulisan Beberapa tahapan penulisan, yaitu

1. Tahap persiapan, pemilihan topik (dikuasai, baru, menarik, bermanfaat), pembatasan topik, pengumpulan pustaka, penentuan tujuan dan maksud, penyusunan kerangka, tahap pengumpulan data, tahap analisis data, tahap penyusunan draf laporan, tahap perbaikan dan pengeditan, tahap pelaporan.

2. Tahap pengumpulan data

3. Tahap analisis data

4. Tahap penyusunan draf laporan

5. Tahap perbaikan dan pengeditan

6. Tahap Pelaporan

C. Sistematika

1. Bagian pembukaan (lembar judul, kata pengantar dan daftar isi)

2. Bagian Isi (pendahuluan, pembahasan, kesimpulan dan saran)

3. Bagian penutup (daftar pustaka, riwayat hidup penulis, dan lampiran-lampiran yang diperlukan)

D. Bahasa Karya Tulis Ilmiah:

1. Baku

2. Denotatif

3. Berkomunikasi dengan pikiran bukan perasaan

4. Kohesif

5. Koheren

6. Mengutamakan kalimat pasif

7. Konsisten
8. Logis

9. Efektif

10.Kuantitatif

\section{KESIMPULAN}

Dari hasil pelaksanaan program pengabdian kepada masyarakat dapat ditarik kesimpulan:

a. Mitra memiliki pengetahuan mengenai karya tulis ilmiah.

b. Mitra memiliki keterampilan karya tulis ilmiah.

c. Mitra memiliki kemampuan untuk meningkatkan pengetahuan kemampuan pembuatan Karya Tulis Ilmiah

d. Pengetahuan dan keterampilan yang guru-guru miliki dalam penyusuan laporan keuangan yang nantinya juga dapat menyebar luaskan guruguru SD Kecamatan Labakkang Kabupaten Pangkep.

\section{UCAPAN TERIMA KASIH}

Ucapan terimakasih disampaikan kepada Rektor UNM atas arahan dan pembinaannya selama proses kegiatan Pengabdian Masyarakat berlangsung. Demikian pula ucapan terima kasih disampaikan kepada Ketua Lembaga Penelitian dan Pengabdian Kepada Masyarakat UNM dan Pemerintah Kabupaten Pangkep Provinsi Sulawesi Selatan, yang telah memberi fasilitas, melakukan monitoring, dan mengevaluasi kegiatan PKM hingga selesai.

\section{DAFTAR PUSTAKA}

Anshari. 2010. Transformasi Pendidikan Islam. Jakarta: Gaung Persada Press.

Kusmayadi, Ismail. 2011. Guru Juga Bisa Menulis.

PT. Reka, Ciganjur, Jayakarsa. Jakarta.

Nugroho, Hery. 2011. Cara MUdah Menjadi Guru Penulis. Semarang; Dahara Prize.

Samani dan Hariyanto. 2011. Konsep dan Model

Pendidikan Karakter. PT Remaja Rosdakarya.

UU No. 14 Tahun 2015. 